\title{
Metacarpal bone dimensions in young and aged South African Bantu consuming a diet low in calcium
}

\author{
AleXANDER R. P. Walker \\ B. F. WALKer \\ D.Sc.
B. D. RICHARDSON
M.Sc.
M.R.C. Human Biochemistry Research Unit, South African Institute for Medical Research, Johannesburg, South Africa

\section{Summary}

Groups of South African Bantu boys and girls of 14 years, compared with local Caucasian children, have lower cortical thickness, cortical score, and crosssection and volume scores for second metacarpal. Yet, when these parameters on groups of aged Bantu men and women, 70-79 years, are compared with published values on corresponding Caucasians, there are no significant differences. Further, aged Bantu have lower prevalences of hip fracture and severe collapse of vertebral bodies. Since a low calcium intake, and in aged Bantu women numerous pregnancies and long lactations, are compatible with satisfactory bone data, it is questioned whether the present insistence on a high calcium intake is justified.

\section{Introduction}

Over $99 \%$ of body calcium is contained in bone. Hence, a habitually low absorption or retention of the element would be expected to affect composition and dimensions of bone. The most plausibly influential factor is level of calcium ingested. Almost invariably, daily intake is less in underprivileged than in sophisticated populations. Yet studies on particular bones in Indian, Bantu, Ugandan and Caucasian subjects have indicated that calcium concentration is fairly constant (Nicholls \& Nimalasuriya, 1939; Walker \& Arvidsson, 1954; Dickerson \& John, 1969). We therefore decided to investigate dimensions of cortex of bone (in the present instance second metacarpal) in two populations accustomed to a low calcium intake, Bantu school-children and aged people, in rural and urban areas. Additionally, in a region where dental fluorosis is marked, calcium intake and bone size were correspondingly investigated. For comparison, mean values for cortical thickness, cortical index, cross-sectional area and volume indices of second metacarpal are available, or have been extrapolated, from publications on Caucasian subjects (Barnett \& Nordin, 1960; Nordin, MacGregor \& Smith, 1966; Morgan et al., 1967; Smith et al., 1969; Hossain, Smith \& Nordin, 1970; Dequecker, 1970; Exton-Smith et al., 1969b; Exton- or Smith, 1970). Such data, of course, relate to persons $\stackrel{+}{\infty}$ used to a relatively high calcium intake.

\section{Subjects \\ School-children}

Pretoria. In 1962-65, interracial studies on school- $\subseteq$ children were carried out by the National Nutrition $\underset{\bar{D}}{ }$ Research Institute, Pretoria. Considerable care wąs $\vec{\varphi}$ taken to obtain representative groups (Fellinghan 1966). At 14 years, the age chosen for this investig tion, mean daily calcium intakes of the groups studie were: Bantu (seventeen boys, seventeen girls) $296 \pm 2 \overrightarrow{62}$ $\mathrm{mg}$ and Caucasians (twenty-seven boys, twenty-two girls) $833 \pm 410 \mathrm{mg}$ (Lubbe, 1968). For the radiology studies, tube distance was $100 \mathrm{~cm}$. X-rays of both hands, undertaken by Dr H. H. Christ, primarily for $\overrightarrow{\overrightarrow{0}}$ bone chronology studies (Christ, 1961), were carried out at Pretoria General Hospital. Measurements of second metacarpal were made as described below.

Kruidfontein and Saulspoort (rural areas). At Lessetlheng Community School, Kruidfontein (135 miles west of Johannesburg), severe fluorosis, manifested by extensive brown stain with pitting of $\frac{O}{3}$ enamel, was present in $92 \%$ of pupils. Drinking water contained 5-14 parts fluorine per million. Eighteen boys and twenty-four girls aged 14 years were $\frac{D}{0}$ examined. Calcium intake was $275 \pm 210 \mathrm{mg}$ per diem. At Moruleng Higher Primary School, Sauls- N poort, 6 miles distant, fluorosis was far less marked. $N$ Drinking water contained 1-3 parts fluorine per $N$ million. Sixteen boys and twenty-one girls of 14 years, $\omega$ showing either no relevant teeth lesions or only slight chalky patches, were examined. Calcium in- $\stackrel{\circ}{C}$

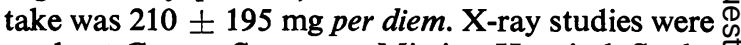
made at George Stegmann Mission Hospital, Sauls- $\stackrel{+}{?}$ poort. Tube distance was $60 \mathrm{~cm}$; bearing in mind the position of second metacarpal on the X-ray plate, $\overrightarrow{\mathbb{D}}$ the angle subtended is small and distortion slight. 


\section{Aged Bantu}

Johannesburg. In the lower middle-class Bantu suburb of Zola North-West, there are twenty-three men and thirty-four women aged 70-79 years. All were X-rayed at Mofolo South Clinic, Soweto (Johannesburg City Health Department). Tube distance was $110 \mathrm{~cm}$. Calcium intake was $320 \pm 265$ $\mathrm{mg}$ per diem. On an average the women had given birth to $6 \cdot 3$ children, and three quarters had breast fed $5 \cdot 1$ children for $6-12$ months.

Kgala. At this village (90 miles west of Johannesburg), seventeen men and twenty-one women were aged 70-79 years. All were X-rayed at Rustenburg Hospital. Tube distance was $100 \mathrm{~cm}$. Mean daily calcium intake was $280 \pm 255 \mathrm{mg}$. The women had had an average of $7 \cdot 8$ children, and had breast fed 6.3 for 9 months or more.

Kruidfontein. At this village (see above), where fluorosis is severe, twenty-four men and thirty women were aged 70-79 years. Of these, twenty-one men and twenty-seven women were X-rayed. Calcium intake was $340 \pm 295 \mathrm{mg}$ per diem. The women had produced an average of $7 \cdot 3$ children and had breast fed 5.9 for 9 months or more.

None of the children nor the aged Bantu had had calcium supplements.

\section{Methods}

\section{Calcium intake}

Among Pretoria children, calcium intake was estimated by the method of Burke \& Stuart (1938) as modified locally by Lubbe (1968). Enquiry was limited to 7 days. Foods were chemically analysed.

For the rest, calcium intake was estimated by a recall procedure for 3 days. The South African food composition tables of Fox (1966) were used.

\section{Radiographs}

Hand radiographs (posterior-anterior) were made as described by Barnett \& Nordin (1960) and by Exton-Smith et al. (1969a). At the mid-point of the second metacarpal of the right hand, measurements were made of external diameter $(D)$ and internal diameter $(d)$. The length $(L)$ also was measured. With plates on the standard viewing box, measurements were made to $0.25 \mathrm{~mm}$, a transparent rule and magnifying glass $(\times 3)$ being used. All measurements were made by two persons; mean differences between measurements of $D, d$, and $L$, were $1 \cdot 5$, 3.8 , and $0.5 \%$, respectively. Calculations were made of total cortical thickness $D-d$, cortical index $\frac{D-d}{D}$ as described by Barnett \& Nordin (1960), cortical area/total area, i.e. $(D / 2)^{2}-(d / 2)^{2} /(D / 2)^{2}$ as used by Hossain et al. (1970), cross-sectional area $D^{2}-d^{2}$ as used by Dequeker (1970), and bone volume index $\frac{D^{2}-d^{2}}{D L}$ as described by Exton-Smith et al. (1969b; Exton-Smith, 1970).

In the aged Bantu subjects, to secure data on the prevalence of fracture of the neck of the femur, and prevalence of obvious collapse of lumbar vertebrae, the following X-rays were taken-(1) anteriorposterior view of pelvis, and (2) lateral and anteriorposterior views of dorsolumbar spine.

\section{Comments on results \\ Calcium intake and loss}

The calcium intakes of both Bantu children and adults were less than half of those of Caucasians (Nordin et al., 1966; Smith et al., 1969). Regarding loss of calcium by old Bantu women, firstly, $30 \mathrm{~g}$ calcium per foetus was assumed (Widdowson \& Spray, 1951). Next, since Bantu babies grow at the same rate as Caucasian babies for the first 6 months (Brock \& Autret, 1952), a milk yield of $750 \mathrm{ml}$ per diem (Wallgren, 1945) was assumed, containing $28 \mathrm{mg}$ calcium $/ 100 \mathrm{ml}$ (Walker et al., 1954). This flow, over 9 months, involves a loss of $57 \mathrm{~g}$ calcium. Hence, calcium loss for six children amounts to $522 \mathrm{~g}$, probably equivalent to over half of the mother's total body calcium prior to child-bearing (Garn \& Wagner, 1969). For Caucasians, loss of calcium for the pregnancy and lactation of three children for 3 months would be $147 \mathrm{~g}$.

\section{Bone data on children}

For the boys, the scores for length, cortical thickness, cortical index, and cross-sectional area and volume indices, were all significantly lower in Pretoria Bantu than in Pretoria Caucasians $(P<$ 0.01). This also applied for Bantu compared with Caucasian girls, save that the mean bone volume index of the Bantu girls was virtually identical to the extrapolated mean value for English girls studied by Exton-Smith et al. (1969b; Exton-Smith, 1970). The lower values in Bantu may be attributed in part to their slower rate of growth. Insufficiency of calcium per se is unlikely to be responsible (Walker, 1954; Garn, Pao \& Rihl, 1964; Luyken \& Luyken-Koning, 1969). In the Pretoria Bantu and Caucasian children, in each racial group the upper and lower quartiles, with respect to calcium intake, had mean cortical dimensions which did not differ significantly. The same type of finding (non-implication of level of calcium intake) has been noted for groups of U.S.A. Caucasian and oriental children (Garn et al., 1964; Garn \& Wagner, 1969), also for different racial groups of children studied in Surinam (Luyken \& Luyken-Koning, 
TABLE 1. Metacarpal dimensions in Bantu children of 14 years compared with data on Caucasians (Means and standard deviations in $\mathrm{mm}$ )

\begin{tabular}{|c|c|c|c|c|c|c|c|c|}
\hline Population & $D$ & $d$ & $D-d$ & $\frac{D-d}{D}$ & $\frac{(D / 2)^{2}-(d / 2)^{2}}{(D / 2)^{2}}$ & $D^{2}-d^{2}$ & $L$ & $\frac{D^{2}-d^{2 C}}{D L}$ \\
\hline \multicolumn{9}{|l|}{ Bantu boys } \\
\hline Pretoria (urban) & $7 \cdot 50$ & $4 \cdot 13$ & $3 \cdot 37$ & 0.45 & $0 \cdot 70$ & $39 \cdot 07$ & $61 \cdot 82$ & 0.084 \\
\hline SD & $0 \cdot 68$ & 0.75 & 0.47 & 0.07 & 0.07 & $6 \cdot 77$ & 4.01 & 0.009 \\
\hline Saulspoort (rural) & $7 \cdot 39$ & $4 \cdot 11$ & $3 \cdot 28$ & 0.45 & 0.69 & $37 \cdot 80$ & $60 \cdot 03$ & 0.084 \\
\hline SD & 0.75 & $0 \cdot 71$ & 0.46 & 0.06 & 0.07 & $7 \cdot 42$ & 3.90 & 0.008 \\
\hline Kruidfontein (fluorosis) & $7 \cdot 37$ & $4 \cdot 37$ & $3 \cdot 00$ & 0.41 & 0.65 & $35 \cdot 22$ & 58.03 & 0.081 \\
\hline SD & 0.64 & 0.66 & 0.55 & 0.07 & 0.06 & $6 \cdot 76$ & 4.43 & $0 \cdot 010$ \\
\hline \multicolumn{9}{|l|}{ Caucasian boys } \\
\hline Pretoria (urban) & $8 \cdot 16$ & 3.57 & 4.59 & 0.56 & $0 \cdot 81$ & $54 \cdot 06$ & $65 \cdot 70$ & $0 \cdot 100$ \\
\hline SD & $0 \cdot 72$ & 0.62 & 0.75 & 0.07 & $0 \cdot 08$ & $10 \cdot 65$ & $4 \cdot 70$ & 0.012 \\
\hline U.S.A. (Garn, 1961) & $7 \cdot 70$ & $3 \cdot 60$ & $4 \cdot 10$ & 0.53 & 0.79 & $46 \cdot 30$ & & \\
\hline England (Exton-Smith, 1970) & & & & & & & & 0.095 \\
\hline \multicolumn{9}{|l|}{ Bantu girls } \\
\hline Pretoria (urban) & $7 \cdot 44$ & $3 \cdot 43$ & $4 \cdot 01$ & 0.54 & 0.79 & $43 \cdot 52$ & 61.99 & 0.094 \\
\hline SD & 0.56 & 0.66 & 0.39 & 0.06 & 0.08 & $5 \cdot 64$ & 4.53 & 0.010 \\
\hline Saulspoort (rural) & $7 \cdot 24$ & $3 \cdot 88$ & $3 \cdot 36$ & 0.46 & 0.71 & $37 \cdot 32$ & $61 \cdot 35$ & 0.083 \\
\hline SD & $0 \cdot 63$ & 0.64 & 0.47 & 0.06 & 0.07 & $6 \cdot 22$ & $3 \cdot 14$ & 0.007 \\
\hline Kruidfontein (fluorosis) & $7 \cdot 22$ & $3 \cdot 58$ & 3.64 & 0.57 & 0.75 & $38 \cdot 58$ & $61 \cdot 64$ & 0.086 \\
\hline SD & 0.44 & 0.94 & $0 \cdot 71$ & $0 \cdot 10$ & 0.07 & $5 \cdot 49$ & $3 \cdot 34$ & 0.010 \\
\hline \multicolumn{9}{|l|}{ Caucasian girls } \\
\hline Pretoria (urban) & $7 \cdot 48$ & 2.94 & $4 \cdot 54$ & $0 \cdot 61$ & 0.85 & $47 \cdot 37$ & $64 \cdot 36$ & 0.097 \\
\hline SD & 0.65 & 0.55 & 0.47 & 0.06 & 0.08 & $7 \cdot 97$ & $2 \cdot 08$ & 0.008 \\
\hline $\begin{array}{l}\text { U.S.A. (Garn, 1969) } \\
\text { England (Exton-Smith, 1970) }\end{array}$ & $7 \cdot 20$ & $2 \cdot 70$ & $4 \cdot 50$ & 0.62 & $0 \cdot 86$ & $44 \cdot 60$ & & 0.095 윰 \\
\hline
\end{tabular}

$D$, external diameter; $d$, internal diameter; $D-d$, cortical thickness; $L$, length; $\frac{D-d}{D}$, cortical index; $\frac{(D / 2)^{2}-(d / 2)^{2}}{(D / 2)^{2}}$ cross-sectional area index; $D^{2}-d^{2}$, cortical area index; $\frac{D^{2}-d^{2}}{D L}$, cortical volume index.

1969). The bearing of race on cortical thickness of metacarpal appears to be variable (Luyken \& Luyken-Koning, 1969).

In the Bantu, values for boys at 14 years were slightly lower than those for girls $(P<0.05)$. This applied in certain respects to the Caucasian groups. A sex difference of this type has been noted by others (Morgan et al., 1969; Garn \& Wagner, 1969). In respect of excessive fluorine intake, the bone data were not significantly affected.

\section{Bone data on adults}

In the aged Bantu groups, mean bone data were either very close to, or lay within corresponding mean values reported for aged Caucasians (Nordin et al., 1966; Morgan et al., 1967; Smith et al., 1969; Garn \& Wagner, 1969; Hossain et al., 1970; Dequeker, 1970; Exton-Smith, 1970).

In the fluorosis area, mean bone data on the aged Bantu did not differ significantly from corresponding data found in the non-fluorosis areas. This was unexpected (Srikantia \& Siddiqui, 1965; Anonymous, 1970).
Among the total of sixty-four aged Bantu men and eighty-five women of 70-79 years examined, none had evidence of hip fracture. In the study of Solomon: (1968) on urban Johannesburg Bantu, age-adjusted윽 prevalence of hip fracture was only a tenth of such reported for corresponding Caucasians. With regard to obvious collapse of lumbar vertebral bodies, in the old Bantu, 6.3 and $11.7 \%$ of males and females respectively, were affected. A low prevalence, $6 \%$, 응 was noted in elderly indigenous inhabitants in Surinam (Luyken \& Luyken-Koning, 1969). In con- $\frac{T}{0}$ trast, in Caucasians in U.S.A., Bernstein et al. (1966) reported such collapse in 45 and $35 \%$ of males and $\tilde{N}$ females, respectively. In an interracial study under- $N$ taken in Durban on female groups of mean age approximately 70 years, Dent, Engelbrecht \& God- $\omega$ frey (1968) reported osteoporosis present in 3 and $2 \%$ of rural and urban Bantu, but in $14 \%$ of Caucasians. A lower prevalence of osteoporosis in U.S.A. $\stackrel{\mathbb{D}}{+}$ Negroes compared with Caucasians has often been reported (Smith \& Rizek, 1966). Unfortunately, in o assessing the frequency of osteoporosis stigmata, different workers use different criteria; notwith- 
TABLE 2. Metacarpal dimensions in aged Bantu compared with data on Caucasians (means and standard deviations in mm)

\begin{tabular}{|c|c|c|c|c|c|c|c|c|}
\hline $\begin{array}{l}\text { Caucasian males } \\
\text { U.S.A. (Garn, 1969) } \\
\text { England (Morgan } \text { et al., 1967) } \\
\text { England (Exton-Smith, 1970) } \\
\text { Holland (Dequeker, 1970) }\end{array}$ & $\begin{array}{l}8 \cdot 60 \\
9 \cdot 70\end{array}$ & $\begin{array}{l}3 \cdot 80 \\
5 \cdot 10\end{array}$ & $\begin{array}{l}4 \cdot 80 \\
4 \cdot 60\end{array}$ & $\begin{array}{l}0.56 \\
0.47\end{array}$ & $\begin{array}{l}0.80 \\
0.72\end{array}$ & $\begin{array}{l}59 \cdot 50 \\
68 \cdot 10 \\
53 \cdot 00\end{array}$ & & 0.097 \\
\hline $\begin{array}{l}\text { Caucasian females } \\
\text { U.S.A. (Garn, 1969) } \\
\text { Scotland (Nordin et al., 1966) } \\
\text { Scotland (Smith } \text { et al., 1969) } \\
\text { Scotland (Hossain et al., 1970) } \\
\text { England (Morgan et al., 1967) } \\
\text { England (Exton-Smith, 1970) } \\
\text { Holland (Dequeker, 1970) }\end{array}$ & $8 \cdot 10$ & $4 \cdot 25$ & $3 \cdot 35$ & $\begin{array}{l}0.44 \\
0.42 \\
0.43 \\
0.39 \\
0.37\end{array}$ & $\begin{array}{l}0.69 \\
0.64 \\
0.63\end{array}$ & $\begin{array}{l}39 \cdot 70 \\
41 \cdot 10 \\
39 \cdot 00\end{array}$ & & 0.082 \\
\hline
\end{tabular}

standing, it would seem justifiable to conclude from our results that the prevalence of such stigmata was lower in Bantu than in Caucasians.

\section{Discussion}

Within the context prevailing, the salient finding is that in aged Bantu, a low calcium intake, and in the old women a very high drain of calcium, are both consistent with metacarpal bone dimensions and indices closely similar to those of Caucasians. Further, among the aged Bantu, also notable were absence of hip fracture and a lower prevalence of obvious collapse of lumbar vertebrae. It should be added that the diet of Bantu not only is low in calcium, but is high in phytic acid, and in the orthodox sense has an unfavourable calcium-phosphorus ratio; the diet, moreover, is frequently low in protein, especially animal protein (Walker, 1966).

Can data on metacarpal be regarded as representative of the bone situation in the body as a whole? It has been demonstrated that cortical dimensions of metacarpal, also humerus, correlate highly significantly $(P<0.001)$ with mineral matter per unit volume (Virtama \& Mahonen, 1960; Virtama \& Tekkla, 1962). Although, as Virtama \& Tekkla (1962) have emphasized, caution is necessary in extrapolating findings from one bone to another, it would seem reasonable to consider that there are no obvious differences in the skeletal stores of aged Bantu compared with Caucasians.

If the foregoing is valid, how is it accomplished? (1) The habitual meagre intake of calcium by Bantu must be very well utilized. There is adequate evidence that low intakes of the element are associated with a high absorption and relatively low excretion (Nicholls \& Nimalasuriya, 1939; Luyken \& Luyken-Koning, 1961; Begum \& Pereira, 1969; Spencer et al., 1969; Garn, 1970). (2) It is probably of relevance that old Bantu are far more active than Caucasians of the same age. All old Bantu studied still busied themselves in and around their dwellings; in rural areas some walk tremendous distances to their cattle posts (as much as 30 miles distant).

At a recent symposium, Whedon (1970) stated, 'Clearly now, many factors, hormonal, nutritional, physical and circulatory influence the rate of bone loss or bone preservation ...' We question whether this is valid for communities. In each of the factors enumerated, our elderly Bantu groups differed markedly from Caucasian groups studied elsewhere. Yet, no significant interracial differences are apparent in mean data on metacarpal dimensions. 
The whole situation will remain unsatisfactory until valid information is available on the lower limits of bone thickness and other indices which, in a community, are consistent with everyday good health and activity.

In the light of our findings, it would seem imperative that the reasons for the present insistence on high calcium intakes during growth, pregnancy and lactation, be critically re-examined. Equally, the continued addition of calcium salts to staple foodstuffs calls for renewed justification.

\section{Acknowledgments}

For facilitating or undertaking the X-ray observations at the hospitals at Pretoria, Rustenburg, Saulspoort, and Johannesburg (Mofolo), we are very grateful to Dr $\mathbf{H}$. $\mathbf{H}$. Christ, Dr F. Jooste, Dr G. H. Roux, and Mrs J. Richards, respectively. Miss M. J. Fick and Miss M. Wadvallah assisted with the cortical measurements.

\section{References}

ANONYMOUs (1970) Fluorides and human health. World Health Organisation Chronicle, 24, 271.

BARNETr, E. \& NoRdIN, B.E.C. (1960) The radiological diagnosis of osteoporosis. A new approach. Clinical Radiology, 11, 166.

Begum, A. \& Pereira, S.M. (1969) Calcium balance studies on children accustomed to low calcium intakes. British Journal of Nutrition, 23, 905.

Bernstein, D.S., Sadowsky, N., Hegsted, D.M., Guri, C.D. \& Stare, F.J. (1966) Prevalence of osteoporosis in high- and low-fluoride areas in North Dakota. Journal of the American Medical Association, 198, 499.

Brock, J.F. \& AUTreT, M. (1952) Kwashiorkor in Africa. Bulletin of the World Health Organisation, 5, 1.

Burke, B.S. \& STUART, H.C. (1938) A method of diet analysis. Application in research and pediatric practice. Journal of Pediatrics, 12, 493.

Christ, H.H. (1961) A discussion of causes of error in the determination of chronological age in children by means of X-ray studies of carpal-bone development. South African Medical Journal, 35, 854.

Dent, C.E., ENGelbrecht, H.E. \& Godfrey, R.C. (1968) Osteoporosis of lumbar vertebrae and calcification of abdominal aorta in women living in Durban. British Medical Journal, 4, 76.

Dequeker, J.V. (1970) Parathyroid activity and postmenopausal osteoporosis. Lancet, ii, 211.

Dickerson, J.W.T. \& JoHN, P.M.V. (1969) The effect of protein-calorie malnutrition on the composition of the human femur. British Journal of Nutrition, 23, 917.

Exton-Smith, A.N. (1970) Pattern of development and loss of bone with age. Lancet, i, 360 .

Exton-Smith, A.N., Millard, P.H., PAyne,P.R. \& Wheeler, E.F. (1969a) Method for measuring quantity of bone. Lancet, ii, 1153.

Exton-Smith, A.N., Millard, P.H., Payne, P.R. \& WheEler, E.F. (1969b) Pattern of development and loss of bone with age. Lancet, ii, 1154.

Fellingham, S.A. (1966) Statistical planning of the nutrition status surveys on Pretoria school children. South African Medical Journal, 40, 228.

Fox, F.W. (1966) Studies on the Chemical Composition of Foods Commonly Used in Southern Africa. South African Institute for Medical Reseárch, Johannesburg.
GARN, S.M. (1970) Calcium requirements for bone building and skeletal maintenance. American Journal of Clinica Nutrition, 23, 1149.

GARN, S.M.. PAO, E.M. \& RihL, M.E. (1964) Compact bone. in Chinese and Japanese. Science, 143, 1439.

GARN, S.M. \& WAGNER, B. (1969) The adolescent growth of the skeletal mass and its implications to mineral requireo ments. In: Adolescent Nutrition and Growth (Ed. by F. P Heald), p. 139. Appleton, Century \& Crofts, New York.

Hossain, M., Smith, D.A. \& Nordin, B.E.C. (1970) Para thyroid activity and post-menopausal osteoporosis尺 Lancet, i, 809.

LuBBe, A.M. (1968) A survey of the nutritional status of white school children in Pretoria: description and come parative study of two dietary survey techniques. South African Medical Journal, 42, 616.

LUBbe, A.M. (1970) Personal communication.

LUYKEN, R. \& LUYKEN-KoNING, F.W.M. (1961) Studies on the physiology of nutrition in Surinam. VIII. Metabolism?. of calcium. Tropical and Geographical Medicine, 13, 46

LUYKEN, R. \& LUYKen-KonING, F.W.M. (1969) Studies on physiology of nutrition in Surinam. XII. Nutrition andA development of muscular, skeletal, and adipose tissues in Surinam children. American Journal of Clinical Nutrition 22, 519.

Morgan, D.B., Spiers, F.W., Pulvertaft, C.N. \& Four은 MAN, P. (1967) The amount of bone in the metacarpal and the phalanx according to age and sex. Clinical Radiology, 18, 101.

Nicholls, L. \& Nimalasuriya, A. (1939) Adaptation to a low calcium intake in reference to the calcium requirements $\overrightarrow{0}$ of tropical populations. Journal of Nutrition, 18, 563. 감

Nordin, B.E.C., MACGregor, J. \& SMITH, D.A. (1966) \$ite incidence of osteoporosis in normal women; its relationdo age and the menopause. Quarterly Journal of Medicine, 3 25.

Smith, D.A., Harrison, I., Nordin, B.E.C., Macgregor J. \& JoRdAN, M. (1968) Mineral metabolism in relation to을 ageing. Proceedings of the Nutrition Society, 27, 201.

SMITH, R.W. \& RIZEK, J. (1966) Epidemiological studies of osteoporosis in women of Puerto Rico and South-eastern? Michigan with special reference to age, race, national origin and to other related or associated findings. Clinical Orthopaedics, 45, 31.

Solomon, L. (1968) Osteoporosis and fracture of the femorato neck in the South African Bantu. Journal of Bone and Joint Surgery, 50 B, 2.

SpenCer, H., Lewin, I., Fowler, J. \& SAmaChson, J. (1969) Influence of dietary calcium intake on $\mathrm{Ca}^{47}$ absorption in man. American Journal of Medicine, 46, 197.

SRIKantia, S.G. \& SiddiQUi, A.H. (1965) Metabolic studies in skeletal fluorosis. Clinical Science, 28, 477.

VirTaMA, P. \& MÄHÖNEN, H. (1960) Thickness of the cortical layer as an estimate of mineral content of the humano finger bones. British Journal of Radiology, 33, 60.

Virtama, P. \& TelkKa, A. (1962) Cortical thickness as an estimate of mineral content of human humerus and femur. British Journal of Radiology, 35, 632.

WALKER, A.R.P. (1954) Does a low intake of calcium retard growth or conduce to stuntedness? American Journal of Clinical Nutrition, 2, 265.

WALKER, A.R.P. (1966) Nutritional, biochemical and other studies on South African populations. South African $\mathbb{Q}$ Medical Journal, 40, 814.

WAlker, A.R.P., Arvidsson, U.B. (1954) Studies on human $\square$ bone from South African Bantu subjects. Part 1. Chemical $O$ composition of ribs from subjects habituated to a diet low $\mathbb{D}$ in calcium. Metabolism, 3, 385. 
Walker, A.R.P., Arvidsson, U.B. \& DraPer, W.L. (1954) The composition of breast milk of South African Bantu mothers. Transactions of the Royal Society of Tropical Medicine and Hygiene, 48, 395.

WALLGREN A. (1945) Breast milk consumption of healthy full-term infants. Acta paediatrica, 32, 778.
Whedon, G.D. (1970) In: Osteoporosis: The state of the art. A Symposium report. American Journal of Clinical Nutrition, 23, 839.

Widdowson, E.M. \& Spray, C.M. (1951) Chemical development in utero. Archives of Disease in Childhood, 26, 205. 